\title{
Significance of Bacterial Variants in Urine of Patients with Chronic Bacteriuria *
}

\author{
Laura T. Gutman, Marvin Turck, $†$ Robert G. Petersdorf, and \\ RALPH J. WEDGWOOD \\ (From the Departments of Pediatrics and Medicine, University of Washington School of Medi- \\ cine, and the King County Hospital, Seattle, Wash.)
}

Some persistent and recurrent bacterial infections of the urinary tract may result from the ability of organisms to remain viable in the kidney as bacterial variants, often termed "protoplasts," "L-forms," or "spheroplasts." These variants are induced in vitro by most antibiotics and by natural immune systems such as serum factors (1), lysozyme (2), and leukocyte granules (3). L-forms have also been produced in vivo in experimental animals (4-6).

Probably every bacterial species is capable of forming a cell wall-free variant. These variants retain the ability to proliferate and may revert to the classical bacterial form, called the parent. Besides lacking a cell wall, bacterial variants differ from the parent because they may be osmotically fragile, reproduce by budding and by production of viable granules, and are filtrable. They also appear to be resistant to killing by serum (7) and to many antibiotics that attack the parent organism (8).

Bacterial variants may include at least several forms. Some are probably bizarre forms not necessarily related to either protoplasts or L-forms. Protoplasts and L-forms may fall along a continuum, and it is often difficult to separate one from the other by their morphological or physicochemical properties. For the purposes of this paper,

\footnotetext{
* Submitted for publication May 3, 1965; accepted August 19, 1965.

This investigation was carried out in part under the sponsorship of the Commission on Immunization of the Armed Forces Epidemiological Board and was supported in part by U. S. Army Medical Research and Development Command grant DA-49-193-MD-2308, by training grants 5 TI-AI-227-03 and AI-146-05, and by grant AI06311-01 from the National Institutes of Health, U. S. Public Health Service.

† Address requests for reprints to Dr. Marvin Turck, Dept. of Medicine, University of Washington School of Medicine, Seattle, Wash. 98105.
}

"protoplasts" and "L-forms" are used interchangeably and are defined as filtrable bacterial forms that appear as granular or budding bodies in broth, grow as distinct colonies on a medium modified for pleuropneumonia-like organisms (PPLO), and may or may not revert to the parent, classical bacterial form on repeated subcultures. PPLO are distinct from L-forms and protoplasts. They are probably a naturally occurring cell wall-free species and do not revert to any other form (9).

In previous studies regarding the pathogenesis of $\mathrm{L}$-forms and protoplasts in urinary tract infection, direct microscopy has shown round, bizarre forms in the urine of patients with bacteriuria receiving antimicrobial agents $(10,11)$. The present study differs from those previously reported in that a modified PPLO medium was used that will support the growth of bacterial variants in patients with chronic bacteriuria and permit further assessment of the role of these forms in the pathogenesis of renal infection. The results on the occurrence of bacterial variants in renal disease suggest that L-formis and protoplasts may be one cause of persistent or chronic infection of the urinary tract.

\section{Methods}

Collection of urine specimens. Urine specimens were carefully collected by a clean-voiding procedure and were separated promptly into three portions: 1) $5 \mathrm{ml}$ was added to a tube containing $5.0 \mathrm{ml}$ of $20 \%$ sucrose solution for osmotic stabilization as suggested by Lederberg $(12)$; 2) $3.0 \mathrm{ml}$ was used on random samples for determination of osmolality by the freezing point technique; 3) $3.0 \mathrm{ml}$ was processed for routine quantitative bacteriologic culture, serologic grouping of Escherichia coli, and antimicrobial susceptibility testing by methods previously described (13).

Separation of bacterial variants from classical organisms. The urine-sucrose solution was transferred to a 10-ml glass syringe fitted with a Luer lock and filtered 
TABLE I

Total experience in culturing for bacterial variants

\begin{tabular}{|c|c|c|c|}
\hline \multicolumn{2}{|l|}{ Study group } & $\begin{array}{l}\text { No. posi- } \\
\text { tive for } \\
\text { variants }\end{array}$ & $\begin{array}{l}\% \text { Posi- } \\
\text { tive for } \\
\text { variants }\end{array}$ \\
\hline \multicolumn{4}{|l|}{$\begin{array}{l}\text { I. Patients with chronic bacteri- } \\
\text { uria or pyelonephritis }\end{array}$} \\
\hline Total no. patients & 57 & 11 & 19 \\
\hline Total no. urine samples & 146 & 23 & 16 \\
\hline \multicolumn{4}{|c|}{$\begin{array}{l}\text { II. Patients with renal disease } \\
\text { other than chronic bacteriuria } \\
\text { or pyelonephritis }\end{array}$} \\
\hline Total no. patients & 59 & $\mathbf{0}$ & 0 \\
\hline Total no. urine samples & 73 & $\mathbf{0}$ & 0 \\
\hline \multicolumn{4}{|l|}{$\begin{array}{l}\text { III. Consecutive admissions for } \\
\text { medical reasons other than } \\
\text { renal disease }\end{array}$} \\
\hline Total no. patients & 15 & $\mathbf{0}$ & 0 \\
\hline Total no. urine samples & 15 & $\mathbf{0}$ & 0 \\
\hline
\end{tabular}

through a $0.45-\mu$ Millipore filter in a Swinny-type syringe adapter. Since L-forms and protoplasts, but not classic bacterial forms, will pass through this pore size (14), variants are separated from classical bacteria.

Preparation of L-form medium. L-form agar medium contained the following (grams per liter) : sucrose 100.0; Phytone ${ }^{1} 20.0 ; \mathrm{NaCl} 5.0 ; \mathrm{MgSO}_{4} \cdot 4 \mathrm{H}_{2} \mathrm{O} 2.5$; yeast extract 2 10.0; cholesterol 0.04 dissolved in $10 \mathrm{ml} 95 \%$ ethanol; Ionagar ${ }^{3}$ no. 2 8.0. The $\mathrm{pH}$ was adjusted to 7.8 with normal $\mathrm{NaOH}$ and the media autoclaved for 15 minutes at $121^{\circ} \mathrm{C}$. L-form broth was prepared by omitting the agar and using $200 \mathrm{~g}$ per $\mathrm{L}$ sucrose.

Horse serum ${ }^{1}$ was heat inactivated before use.

Pour plates were made by adding $2 \mathrm{ml}$ horse serum, $8 \mathrm{ml} \mathrm{L}$-form agar, and inoculum. Falcon $12-\times 50-\mathrm{mm}$ petri dishes with tight covers were used to prevent drying of media during prolonged incubation.

A second pour plate contained horse serum, L-form agar, inoculum, and $25 \mu \mathrm{g}$ per $\mathrm{ml}$ of tetrazolium red indicator.

Biphasic tube medium contained L-form broth on top of an L-form agar slant. One $\mathrm{ml}$ horse serum was added to $3 \mathrm{ml}$ agar and cooled as a slant. Eight $\mathrm{ml} \mathrm{L-form}$ broth, $2 \mathrm{ml}$ horse serum, and inoculum were decanted onto this.

Culture procedures for isolation of variants. The urine filtrate was processed as follows : 1) $0.25 \mathrm{ml}$ was inoculated into an L-form medium pour plate; 2) $0.25 \mathrm{ml}$ was inoculated into an L-form medium pour plate containing $25 \mu \mathrm{g}$ per $\mathrm{ml}$ tetrazolium red indicator; 3) $0.1 \mathrm{ml}$ was inoculated onto a standard sheep blood agar plate; 4) a drop was examined directly by phase contrast microscopy; 5) the remainder of the filtrate was inoculated into biphasic L-form medium. All plates were incubated aerobically at $37^{\circ} \mathrm{C}$. The blood agar plates served as a check on contamination by classical bacterial forms, and

${ }^{1} \mathrm{BBL}$, Baltimore, Md.

2 Difco, Detroit, Mich.

3 Oxoid, Chicago Heights, Ill. the samples were discarded if urine filtrate produced growth on the blood plate. The initial cultures were examined at 3 to 7 days by direct observation. One week after initial inoculation, $1.0 \mathrm{ml}$ of broth from the biphasic medium was subcultured into an $\mathrm{L}$-form medium pour plate and into a second biphasic broth. One and 2 weeks later, the second biphasic broth was subcultured into L-form medium pour plates. All broth cultures were examined by phase contrast microscopy for evidence of variant growth. All cultures were held for 1 month before being discarded as negative. An uninoculated biphasic tube and a pour plate were prepared along with the study specimens to serve as sterility controls; if these showed growth, presumably evidence of contamination, the samples made from that particular urine preparation were discarded.

Criteria for growth of bacterial variants. L-form and protoplast colonies are small and may appear only after prolonged incubation. Only those samples that showed growth of colonies on L-form medium agar plates were considered positive, including colonies that were macroscopically visible in the agar and colonies that reduced the indicator dye to visible pink and red. Although slightly inhibitory to variant growth, the tetrazolium red indicator was useful because the color change of dye, indicative of metabolic activity, allowed for more rapid screening of plates. Forms that could be identified only in the broth, or forms that were visible in the agar only by microscopy, were not accepted because of possible artifacts.

Attempts at reversion of L-form colonies. Variants may readily revert to the parent form on the first or second subculture. In general, this has occurred in patients receiving treatment with antimicrobial agents. If the culture failed to revert, the variants were serially inoculated into media of decreasing horse serum concentration $(20 \%, 15 \%, 10 \%, 5 \%$ serum $)$, into broth containing $50 \%$ L-form broth and $50 \%$ trypticase soy broth, ${ }^{1}$ and on one occasion into an animal, for animal passage.

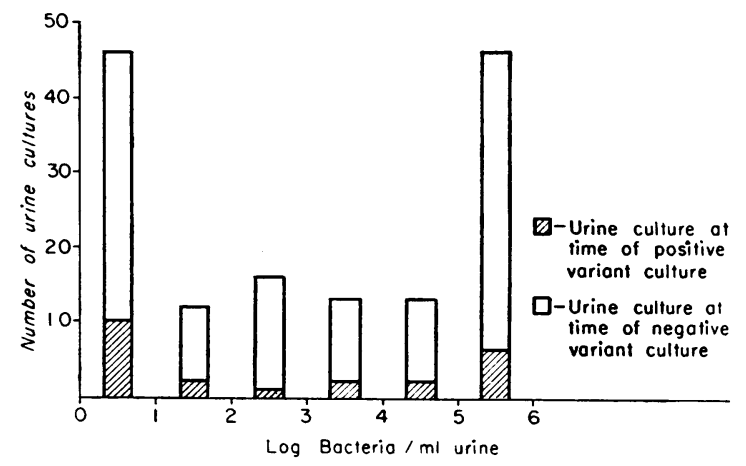

Fig. 1. Distribution of 23 URINe cultures positive FOR VARIANTS IN RELATION TO 146 ROUTINE BACTERIAL COUNTS. 
TABLE II

Bacteriologic and clinical data of patients with and without variants

\begin{tabular}{|c|c|c|c|c|c|c|c|}
\hline \multirow[b]{2}{*}{$\begin{array}{l}\text { Patient } \\
\text { no. }\end{array}$} & \multicolumn{4}{|c|}{ Routine urine cultures at time culture for variant was positive } & \multicolumn{3}{|c|}{$\begin{array}{l}\text { Routine urine cultures at time culture for } \\
\text { variant was negative }\end{array}$} \\
\hline & \multicolumn{2}{|c|}{ Routine culture } & \multirow[t]{2}{*}{ Reversion } & \multirow{2}{*}{$\begin{array}{c}\begin{array}{c}\text { Concurrent } \\
\text { antimicrobial } \\
\text { therapy }\end{array} \\
\text { Ampicillin } \\
\text { Ampicillin }\end{array}$} & \multicolumn{2}{|l|}{ Routine culture } & $\begin{array}{l}\text { Concurrent } \\
\text { antimicrobial } \\
\text { therapy }\end{array}$ \\
\hline 1. & $\begin{array}{l}\text { Negative } \\
\text { Escherichia coli }\end{array}$ & $>10^{3}$ & & & $\begin{array}{l}\text { Negative } \\
\text { Escherichia coli }\end{array}$ & $>10^{4}$ & $\begin{array}{l}\text { Ampicillin } \\
\text { Ampicillin }\end{array}$ \\
\hline 2. & $\begin{array}{l}\text { Escherichia coli } \\
\text { Klebsiella } \\
\text { Klebsiella }\end{array}$ & $\begin{array}{l}>10^{5} \\
<10^{2} \\
<10^{2}\end{array}$ & $\begin{array}{l}\text { None } \\
\text { None } \\
\text { None }\end{array}$ & $\begin{array}{l}\text { Ampicillin } \\
\text { Ampicillin } \\
\text { Ampicillin }\end{array}$ & $\begin{array}{l}\text { Negative (8 samples) } \\
\text { Escherichia coli } \\
\quad(5 \text { samples })\end{array}$ & $>10^{5}$ & Ampicillin \\
\hline 3. & $\begin{array}{l}\text { Escherichia coli } \\
\quad \text { and Proteus mi }\end{array}$ & $\begin{array}{l}>10^{4} \\
\text { irabilis }\end{array}$ & Escherichia coli & $\begin{array}{c}\text { Ampicillin } \\
\text {. }\end{array}$ & $\begin{array}{l}\text { Escherichia coli and } \\
\text { Proteus mirabilis } \\
\text { Proteus mirabilis and } \\
\text { Escherichia coli } \\
\text { Klebsiella (2 samples) } \\
\text { Negative }\end{array}$ & $\begin{array}{l}>10^{4} \\
>10^{3} \\
<10^{2}\end{array}$ & $\begin{array}{l}\text { None } \\
\text { None } \\
\text { None } \\
\text { None }\end{array}$ \\
\hline 4. & $\begin{array}{l}\text { Escherichia coli } \\
\text { Escherichia coli } \\
\text { Negative } \\
\text { Escherichia coli } \\
\text { Escherichia coli } \\
\text { Negative }\end{array}$ & $\begin{array}{l}>10^{5} \\
<10^{2} \\
>10^{5} \\
<10^{2}\end{array}$ & $\begin{array}{l}\text { None } \\
\text { None } \\
\text { None } \\
\text { Escherichia coli } \\
\text { Escherichia coli } \\
\text { Escherichia coli }\end{array}$ & $\begin{array}{l}\text { Ampicillin } \\
\text { Ampicillin } \\
\text { Ampicillin } \\
\text { Ampicillin } \\
\text { Ampicillin } \\
\text { Ampicillin }\end{array}$ & $\begin{array}{l}\text { Negative (16 samples) } \\
\text { Escherichia coli } \\
\quad \text { (11 samples) }\end{array}$ & $>10^{5}$ & $\begin{array}{l}\text { Ampicillin } \\
\text { None }\end{array}$ \\
\hline 5. & Escherichia coli & $>10^{5}$ & None & None & & & \\
\hline 6. & $\begin{array}{l}\text { Streptococcus } \\
\text { faecalis }\end{array}$ & $>10^{5}$ & $\begin{array}{l}\text { Streptococcus } \\
\text { faecalis }\end{array}$ & None & & & \\
\hline 7. & Negative & & None & None & $\begin{array}{l}\text { Staphylococcus and } \\
\text { Streptococcus }\end{array}$ & $>10^{4}$ & None \\
\hline 8. & $\begin{array}{l}\text { Escherichia coli } \\
\text { Negative }\end{array}$ & $>10^{5}$ & $\begin{array}{l}\text { Escherichia coli } \\
\text { Escherichia coli }\end{array}$ & $\begin{array}{l}\text { Cephalothin } \\
\text { Cephalothin }\end{array}$ & & & \\
\hline 9. & Escherichia coli & $>10^{5}$ & None & Chloramphenicol & Escherichia coli & $>10^{5}$ & None \\
\hline 10. & Negative & & None & None & & & \\
\hline $11 . *$ & $\begin{array}{l}\text { Negative } \\
\text { Negative } \\
\text { Negative } \\
\text { Negative }\end{array}$ & & $\begin{array}{l}\text { None } \\
\text { None } \\
\text { None } \\
\text { None }\end{array}$ & $\begin{array}{l}\text { None } \\
\text { None } \\
\text { None } \\
\text { None }\end{array}$ & & & \\
\hline
\end{tabular}

* A renal biopsy from this patient was positive for variants, which subsequently reverted to Proteus mirabilis.

\section{Results}

Prevalence of bacterial variants in different population groups. The data relating to isolation of bacterial variants are summarized in Table I. These patients were from three study groups. Group I included patients with chronic bacteriuria or pyelonephritis. The majority of these patients had had persistent or repeated episodes of significant bacteriuria, defined as greater than $10^{5}$ bacteria per $\mathrm{ml}$ urine. In this group 11 of 57 patients were found to have bacterial variants in their urine on one or more occasions. Figure 1 depicts the distribution of cultures positive for variants in relation to routine quantitative bacterial counts. The greatest number of urine samples positive for variants was obtained at a time when the patients were receiving antimicrobial therapy and con- tained between 0 and 10 classical organisms per $\mathrm{ml}$ urine. Variants were cultured sometime during the period of observation in 23 of 146 (16\%) specimens and 11 of $57(19 \%)$ patients with chronic infection of the urinary tract.

Group II included 59 patients with renal disease other than urinary tract infection. Diagnoses in this group included chronic glomerulonephritis, collagen vascular disease, diabetic nephropathy, polycystic disease, and familial nephritis. Patients who showed concomitant bacteriuria were excluded from the study. No variants were isolated from patients in this group. Variants were also not isolated from patients in group III, which consisted of 15 consecutive patients admitted to the hospital for reasons other than renal disease. 

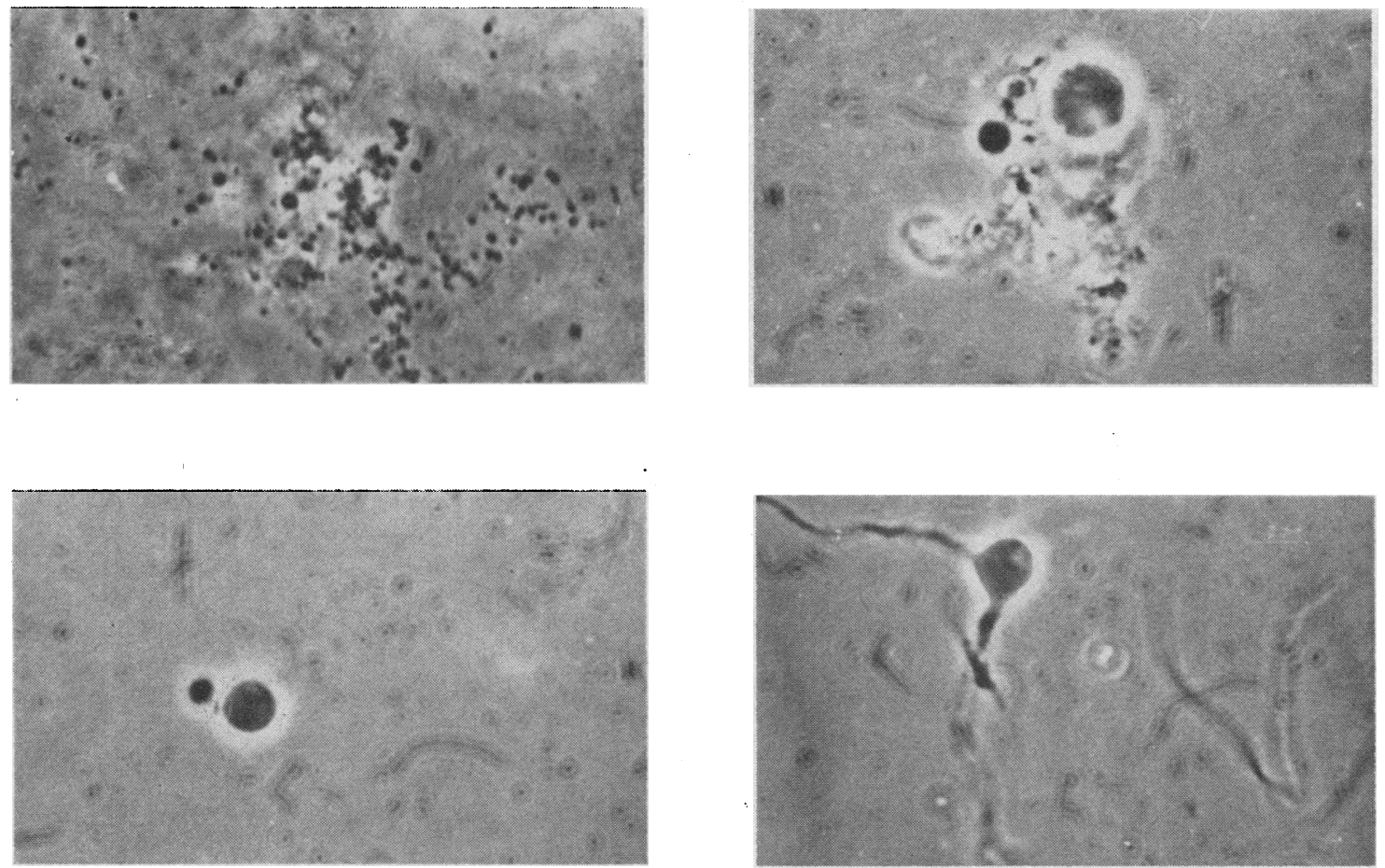

Fig. 2. Various features of variants as SEen by Phase microscopy. 'Upper left: A variant colony within an agar block. Notice the cluster of organisms in the center of the colony. These organisms were obtained from Patient 4, and reverted to E. coli (agar smash $\times 300$ ).

Upper right: A stable L-form or protoplast isolated from the urine of Patient 11. Notice the large body surrounded by granules and spheres in various stages of development. These mature to become variants (wet mount of broth culture $\times 3,000$ ).

Lower left: A budding protoplast obtained from Patient 3; these variants reverted to $E$. coli (wet mount of broth culture $\times 3,000$ ).

Lower right: A variant during the process of reversion to Proteus mirabilis isolated from the kidney biopsy of Patient 11. The long filamentous extensions from the central round body segment to become bacilli (wet mount of broth culture $\times 3,000$ ).

When variants were found on the L-form medium, they were always present in large numbers and reduced the tetrazolium indicator dye. Their small size, however, precluded precise quantitation. When only a few isolated colonies were cultured on L-form agar, they were found to be either diphtheroids or staphylococci, presumably contaminants. In no instance was a colony similar to a variant either morphologically or by phase microscopy found on blood agar. The rigid criteria employed for definition of positive cultures for bacterial variants plus the fact that they were always present in large numbers make it unlikely that their failure to grow on blood agar was a chance occurrence. When colonies of typical variants were found on L-form agar, budding or granular forms were also demonstrated in broth.
There were, however, five instances not included in tabulation of the data, four in patients with chronic bacteriuria and one in a patient with renal disease other than chronic pyelonephritis, in which microscopic examination of the broth showed "typical" budding or granular forms, but growth failed to occur on solid media; these patients' urines were not considered positive for variants.

Characteristics of patients with bacterial variants in urine. The bacteriologic and clinical data of the 11 patients from whom L-forms or protoplasts were recovered are summarized in Table II. Although bacterial variants were usually demonstrated at a time when the patient was receiving concurrent antimicrobial therapy, cultures for variants were also positive from five patients at 
TABLE III

Patients studied for bacterial variants while receiving antimicrobial therapy

\begin{tabular}{|c|c|c|c|}
\hline Patient no. & Infecting organism & Variant culture & After therapy \\
\hline $\begin{array}{l}1 \\
2 \\
4 \\
9\end{array}$ & $\begin{array}{l}\text { Streptococcus faecalis and } \\
\text { Escherichia coli } 04 \\
\text { Escherrchia coli } 07 \\
\text { Escherichia coli } 016-62 \\
\text { Escherichia coli }\end{array}$ & $\begin{array}{l}+ \\
+ \\
+ \\
+\end{array}$ & $\begin{array}{l}\text { Streptococcus faecalis and } \\
\text { Escherichia coli 04 } \\
\text { Escherichia coli 07 } \\
\text { Escherichia coli 016-62 } \\
\text { Escherichia coli }\end{array}$ \\
\hline $\begin{array}{l}12 \\
13 \\
14 \\
15 \\
16\end{array}$ & $\begin{array}{l}\text { Escherichia coli } \\
\text { Escherichia coli } \\
\text { Intermedia te coliform } \\
\text { Escherichia coli } \\
\text { Escherichia coli } 075\end{array}$ & $\begin{array}{l}\bar{z} \\
\bar{z} \\
\bar{z}\end{array}$ & $\begin{array}{l}\text { Klebsiella } \\
\text { No relapse } \\
\text { Proteus mirabilis } \\
\text { No relapse } \\
\text { Escherichia coli } 075\end{array}$ \\
\hline
\end{tabular}

a time when they had not received therapy for at least 6 weeks; in one patient no known antimicrobial treatment had been given.

In Table II are also listed the results of routine quantitative urine cultures and the state of antimicrobial therapy at a time when these 11 patients did not have bacterial variants isolated from the urine. A total of 49 specimens was examined from which variants could not be identified, 26 during antimicrobial treatment and 23 without concurrent therapy. In all, 23 samples from these 11 patients showed growth of variants, and in seven instances the variant subsequently reverted to a classical bacterial form, which was the same species or serogroup of organism with which the patient had been infected initially. Urine samples from three patients (no. 7, 10, and 11) were positive for variants at a time when the routine bacteriologic culture was negative and when the patient was not receiving chemotherapy. Patient 11 was of particular interest. She was admitted to the hospital because of progressive azotemia of unknown etiology. She was found to have multiple myeloma, but in addition, renal biopsy revealed histologic evidence of pyelonephritis. Variants were cultured from homogenates of the tissue specimen and ultimately reverted to classical Proteus mirabilis. Urinary variants, which were demonstrated on four separate occasions, failed to revert to the parent. However, a passage of these stable variants into rats resulted in isolation of forms that readily reverted to $P$. mirabilis. Renal tissue obtained at post-mortem also grew variants that failed to revert to classical bacterial forms.

A second patient (No. 4) had been followed for asymptomatic bacteriuria for 5 years and con- sistently harbored the same strain of $E$. coli 016-62. During this period of observation she had remained completely asymptomatic despite persistent bacteriuria; she had also remained relatively refractory to attempts at eradication of infection because of her inability to tolerate oral antimicrobial agents for more than a few days at a time. Because variants were demonstrated in her urine during treatment with ampicillin, she was admitted to the hospital for further treatment and study. Percutaneous renal biopsy was performed, and classical $E$. coli $016-62$ was cultured from the tissue homogenate although variants could be identified only in the urine. A course of parenteral ampicillin, $2 \mathrm{~g}$ per day for 10 days, was administered with prompt sterilization of the urine, but subsequently the infection relapsed with $E$. coli 016-62, shortly after cessation of therapy. Erythromycin had also been added to the treatment regimen because of apparent in vitro susceptibility of the variants to this antibiotic. However, addition of this agent did not prevent recrudescence of bacteriuria with the same serological strain of $E$. coli.

Figure 2 depicts characteristic examples of an agar smash of a variant colony, stable granular variant forms, budding, and filamentous forms identified from patients in this study.

Isolation of bacterial variants during therapy. Nine patients were studied for the presence of L-forms or protoplasts before, during, and after antibiotic treatment (Table III). These represented a selected sample because not all patients were studied serially in relation to chemotherapy. Eight of the patients in this group had received several courses of antimicrobials for chronic urinary tract infection in the past and either were 
refractory to treatment or had had recurrences after cessation of therapy. Although all nine patients became abacteriuric during therapy, only two remained free of significant infection for at least 6 weeks after therapy. All relapses occurred within 1 week of cessation of treatment. Variants were cultured from the urine of four of these nine patients, and it is noteworthy that recurrences of infection among them were associated with the same organism or serogroup of $E$. coli that was present before therapy. Although relapse of infection with the same strain of E. coli 075 was also found in one patient from whom L-forms or protoplasts were not grown, it is of particular interest that this patient had renal lithiasis, and relapse of infection was not unexpected.

\section{Discussion}

The existence of a filtrable stage of bacterial variation has been recognized since the early part of this century. In 1931, Hadley, Delves, and Klimek (15) reviewed the field of filtrable bacteria and suggested that they were associated with chronic infectious disease. In 1935, Klieneberger noticed a small colony variant on a plate of Streptobacillus moniliformis (16). She originally believed this to be a symbiont. Subsequently, however, it was determined to be a variant form of the Streptobacillus.

The colony studied by Klieneberger arose spontaneously from a culture of classical bacteria. Since then, bacterial variants have been produced from virtually all species of bacteria (and yeast) by means of various stimuli. Adverse conditions in general, such as prolonged incubation, incubation at suboptimal temperatures, and high amino acid and salt concentrations will predispose to L-form transformation (1). Exposure of bacteria to many antibiotics may also produce variants (17). The transformation from the classical bacterial to the variant form is probably a general response of the organism rather than the result of a specific action of the variant-producing agent upon the bacteria. For example, a history of antimicrobial therapy may not be a necessary prerequisite for bacterial variants in human infection.

Since these studies were concerned primarily with urinary tract infections, they were limited mainly to enteric bacterial variants. These gram- negative variants will pass a $0.45-\mu$ Millipore filter, which restricts classical organisms. Morphologically they are round, vary in size, and are seen most easily by phase contrast microscopy. They take Dienes' methylene blue azure stain $(18,19)$. On gram stain they break up and are seen only as debris unless precautions are taken to prevent their lysis by the hypotonic fixative (11). They do not grow in trypticase soy broth or blood agar plates and grow as very small, opaque colonies in the L-form medium described above. Their small size and the extreme difficulty in propagating these variants on solid media make precise enumeration of these forms impossible at this time. Protoplasts and L-forms produced from gram-positive organisms, on the other hand, tend to be much larger and may be quantitated (8).

In attempting to relate variants to the pathogenesis of infection of the kidney, it may be worthwhile to attempt to distinguish protoplasts from $\mathrm{L}$-forms. There is evidence that $\mathrm{L}$-forms are not so osmotically fragile as are protoplasts (20), and the greater osmotic stability of the L-form may, in part, explain its survival in the isotonic environment of the body. Distinct from L-forms, protoplasts may lyse in an isotonic milieu, and the renal medulla alone may be sufficiently hypertonic to support their growth. It is also conceivable that protoplasts are formed in the renal medulla during infection and subsequently develop into stable $\mathrm{L}$-forms that can be recovered from the urine. In pursuing this question, urinary osmolality has been determined on some urine samples from which variants were isolated and from a number of control specimens. To date the total number of samples is too small to draw definitive conclusions, but none with an osmolality below $312 \mathrm{mOsm}$ have yielded L-forms or protoplasts. The effect of urinary osmolality on isolation of bacterial variants has not been settled and is under continued study.

Bacterial variants in the urine after antibiotic therapy have been reported previously. In 1951, Voureka observed bizarre bacterial forms in the urine of patients who were treated with chloramphenicol and also noted their reversion to the parent form after repeated subcultures (10). Ten years later Braude, Siemienski, and Jacobs reported a patient with Proteus pyelonephritis in whose urine round, osmotically fragile forms were 
found during penicillin therapy (11). When these organisms were injected into the bladder of rats, a Proteus pyelonepritis was produced 7 to 8 days later.

Guze and Kalmanson incriminated protoplasts in the persistent infection that characterizes Streptococcus faecalis pyelonephritis in rats (21). Rats were inoculated with $S$. faecalis and treated with penicillin. After therapy had been completed, the kidneys were homogenized in salt solution, and the homogenates were then inoculated into osmotically stabilized and standard media. The number of classical colonies was enumerated, and the difference between colony counts on the two media was taken to be the number of osmotically fragile protoplasts originally present. In these studies the kidneys were often sterile on routine media, whereas a significant number of colonies, presumably representing reverted protoplasts, occurred on the osmotically stabilized media.

Alderman and Freedman (22) injected E. coli protoplasts, produced from the parent by contact with penicillin, into the renal medulla and into the skin of rabbits. The animals developed $E$. coli pyelonephritis presumably from reverted protoplasts. However, the protoplasts injected into the dermis failed to produce evidence of infection. It was inferred from these data that the higher osmolality of the renal medulla favored survival and reversion of protoplasts, whereas the organisms in the isotonic dermis had lysed.

When bacterial variants are recovered from the urine of patients receiving antimicrobials, especially ampicillin and cephalothin, which act primarily on the cell wall, the question can be raised as to whether these variants are formed in vivo or whether induction has occurred after voiding has taken place. There are at least four reasons to believe that in urinary tract infection L-forms and protoplasts are induced in vivo. First, these forms have been observed by direct microscopy of freshly voided urine; second, in the isolation procedures performed in the present study, antibiotics in the urine were probably diluted to a concentration far below that required to produce protoplasts in vitro; third, the urine specimens were promptly filtered, excluding classical forms from the filtrate; finally, urine samples from some patients who were not receiving antibiotics contained variants.
The finding that the antibiotic sensitivity pattern of a variant usually differs from that of its parent (23) has opened up new therapeutic considerations in patients with chronic bacteriuria. Guze and Kalmanson (24) have demonstrated that when rats with $S$. fecalis pyelonephritis are treated with penicillin, followed by erythromycin, protoplasts fail to persist. In contrast, when penicillin alone is used, protoplasts can be demonstrated many weeks after therapy has ended. Although this type of approach has not been tried in patients, it deserves consideration. Whether variants themselves are pathogenic and are capable of tissue invasion, apart from their ability to revert to a pathogenic classical organism, remains to be determined. Some variants of gram-negative rods exert cytopathogenic action on cells in tissue culture (25) and therefore may cause progressive disease in vivo. Variants may be pathogenic, and it is important to be able to identify them and to define their relation to chronic infection.

The identification of bacterial variants in pyelonephritis may have wide implications. First, variants cannot be isolated and identified by the usual techniques in use in classical bacteriology, and as was the case with PPLO or viral cultures, techniques for isolation of variants extend the area of clinical microbiology. The success of this study depended in part on the preparation of a medium suitable for the growth of variants and on a method for separating variants from classical bacteria without the use of inhibitors. Second, if variants are causal agents in some cases of chronic pyelonephritis, some concepts of the diagnosis and treatment of this relatively common disease will have to be re-evaluated. On the basis of this study, approximately $20 \%$ of patients with chronic bacteriuria may have protoplast or L-form infection of the kidney at some time in their course. Third, if L-forms appear as a result of antibiotic therapy, and are in themselves pathogenic, eradication of bacteriuria can no longer be considered as the sole criterion for successful treatment of urinary tract infection. Finally, since the antibiotic sensitivity pattern of variants differs from the parent, the identification of variants as pathogenic agents would necessitate some changes in concepts of antibiotic therapy. 


\section{Summary}

A total of 234 urine cultures was processed from 131 patients. L-forms or protoplasts were demonstrated from 11 of 57 (19\%) patients with chronic urinary tract infection and pyelonephritis. No filtrable bacterial variants were cultured from urine of 59 patients with renal disease other than chronic bacteriuria or from 15 consecutively hospitalized patients without renal disease. Methods of isolating and culturing enteric bacterial variants were described. Patients from whom variants were identified during treatment with antibiotics were shown to relapse with the original parent strain when therapy was completed. These observations suggest that L-forms and protoplasts may play a role in microbial persistence of chronic renal infection.

\section{References}

1. Dienes, L., H. J. Weinberger, and S. Madoff. The transformation of typhoid bacilli into $\mathrm{L}$ forms under various conditions. J. Bact. 1950, 59, 755.

2. Weibull, D. The isolation of protoplasts from Bacillus megaterium by controlled treatment with lysozyme. J. Bact. 1953, 66, 688.

3. Amano, T., Y. Seki, K. Fujikawa, S. Kashiba, T. Morioka, and S. Ichikawa. The isolation and characterization of protoplasts from Escherichia coli B with the treatment of leukocytes extract. Med. J. Osaka Univ. 1956, 7, 245.

4. Carey, W. F., L. H. Muschel, and L. S. Baron. The formation of bacterial protoplasts in vivo. J. Immunol. 1960, 84, 183.

5. Kagan, G. Ja. Review of pathogenicity of L-forms. Klin. Med. (Mosk.) 1961, 39, 12.

6. Pfeiffer, R. Weitere Untersuchungen über das Wesen des Choleraimmunität. Z. Hyg. Infekt.-Kr. 1894, 18, 1.

7. Gutman, L. T., M. Turck, R. G. Petersdorf, and R. J. Wedgwood. Unpublished data.

8. Kagan, B. M., C. W. Molander, S. Zolla, E. M. Heimlich, H. J. Weinberger, R. Busser, and S. Liepnicks. Antibiotic sensitivity and pathogenicity of L-phase variants of staphylococci. Antimicrob. Agents Chemother. 1963, 517.
9. Edward, D. G., and E. A. Freundt. The classification and nomenclature of organisms of the pleuropneumonia group. J. gen. Microbiol. 1956, 14, 197.

10. Voureka, A. Bacterial variants in patients treated with chloramphenicol. Lancet 1951, 1, 27.

11. Braude, A. I., J. Siemienski, and I. Jacobs. Protoplast formation in human urine. Trans. Ass. Amer. Phycns 1961, 74, 234.

12. Lederberg, J. Bacterial protoplasts induced by penicillin. Proc. nat. Acad. Sci. (Wash.) 1956, 42, 574.

13. Lindemeyer, R. I., M. Turck, and R. G. Petersdorf. Factors determining the outcome of chemotherapy in infections of the urinary tract. Ann. intern. Med. 1963, 58, 201.

14. Klieneberger-Nobel, E. On Streptobacillus moniliformis and the filtrability of its L-form. J. Hyg. (Lond.) 1949, 47, 393.

15. Hadley, P., E. Delves, and J. Klimek. The filtrable forms of bacteria. J. infect. Dis. 1931, 48, 1.

16. Klieneberger, E. The natural occurrence of Pleuropneumonia-like organisms in apparent symbiosis with Streptobacillus moniliformis and other bacteria. J. Path. Bact. 1935, 40, 93.

17. Brien, G., L. Ellis, and C. W. Godzeski. Survival in vivo (in ovo) of L-phase bacteria. Antimicrob. Agents Chemother. 1962, 854.

18. Klieneberger-Nobel, E. Pleuropneumonia-like Organisms (PPLO) Mycoplasmataceae. London, Academic Press, 1962, p. 31.

19. Dienes, L. Morphology and nature of the pleuropneumonia group of organisms. J. Bact. 1945, 50, 441.

20. Razin, S., and M. Argaman. Lysis of mycoplasma, bacterial protoplasts, spheroplasts and L-forms by various agents. J. gen. Microbiol. 1963, 30, 155.

21. Guze, L. B., and G. M. Kalmanson. Persistence of bacteria in "protoplast" form after apparent cure of pyelonephritis in rats. Science 1963, 143, 1340.

22. Alderman, M. H., and L. R. Freedman. Experimental pyelonephritis. X. The direct injection of $\mathrm{E}$. coli protoplasts into the medulla of the rabbit kidney. Yale J. Biol. Med. 1963, 36, 157.

23. Ward, J. R., S. Madoff, and L. Dienes. In vitro sensitivity of some bacteria, their L forms, and pleuropneumonia-like organisms to antibiotics. Proc. Soc. exp. Biol. (N. Y.) 1958, 97, 132.

24. Guze, L. B., and G. M. Kalmanson. Action of erythromycin on "protoplasts" in vivo. Science 1964, 146, 1299.

25. Lavillaureix, J. Action de formes L pathogènes sur des cultures de cellules cancéreuses. C. R. Acad. Sci. (Paris) 1957, 244, 1098. 